\title{
Prevalence of Gender Based Violence for having Girl Child, Women's Reaction and Empowerment among Mothers Attending Postpartum OPD in a Selected Medical College, West Bengal
}

\author{
Soujita Mukherjee', Smritikana Mani
}

${ }^{1}$ Department of Obstetrics and Gynaecological Nursing, College of Nursing, Medical College and Hospital, Kolkata, Bengal, India. ${ }^{2}$ Principal, College of Nursing, Medical College and Hospital, Kolkata, Bengal, India.

DOI: https://doi.org/10.24321/2455.9318.202017

\section{I $\quad \mathbf{N} \quad \mathbf{F} \quad \mathbf{O}$}

\section{Corresponding Author:}

Soujita Mukherjee, Department of Obstetrics and Gynaecological Nursing, College of Nursing, Medical College and Hospital, Kolkata, Bengal, India

E-mail Id:

soujita.mukherjee@gmail.com

Orcid Id:

https://orcid.org/0000-0003-4696-6444

How to cite this article:

Mukherjee S, Mani S. Prevalence of Gender Based Violence for having Girl Child, Women's Reaction and Empowerment among Mothers Attending Postpartum OPD in a Selected Medical College, West Bengal. Int J Nurs Midwif Res 2020; 7(2): 38-43.

Date of Submission: 2020-10-21

Date of Acceptance: 2020-11-18

\section{$\begin{array}{llllllll}\mathbf{A} & \mathbf{B} & \mathbf{S} & \mathbf{T} & \mathbf{R} & \mathbf{A} & \mathbf{C} & \mathbf{T}\end{array}$}

Background: Gender based violence is a global problem and is still a key concern in developing countries. A survey was undertaken to assess prevalence of gender based violence for having girl child, women's reaction and empowerment among mothers.

Methods: The conceptual framework was based on "The Duluth Model". Clearance from the institutional ethical committee and individual consent were taken. Descriptive survey design was adopted. From the population of postnatal women 162 were selected as sample by purposive sampling technique from postnatal OPD. Final data were collected for 6 weeks by using a validated and reliable semi-structured interview schedule $(r=0.98)$ and structured interview schedule $(r=0.83)$.

Result: The study findings revealed that $22.83 \%$ women faced gender based violence. Majority faced emotional violence (59\%) and sexual violence (57\%). Women's no rejection towards girl child was $91.35 \%$ whereas only $8.64 \%$ had indifferent view. In the domain of women empowerment $64.19 \%$ expressed as well empowered but decision making in the area of political (38.8\%), economical (19.75\%) and educational (12.96\%) was poor. The association between gender based violence and women empowerment is statistically significant (chi2 value $\left.=48.03^{*}, \mathrm{p}<0.05\right)$.

Conclusion: It can be concluded that gender based violence is till now a case of concern for our society and country. The study has it's implication in the field of nursing practice for awareness on violence and women's right during pregnancy and after child birth.

Keywords: Gender Based Violence, Empowerment, Women's Reaction Towards Girl Child 


\section{Introduction}

Gender based violence, also known as gender violence or gendered violence is used to denote harm inflicted upon individuals and groups that is connected to normative understanding of gender. ${ }^{1}$ Gender based violence is violence targeted at individual or group on the basis of gender. The phenomenon of gender based violence is deeply rooted in gender inequality. It is violation of also human rights. Gender based violence can be defined as any act that result in harm or suffering of women physically, sexually or psychologically. These may include any threat or deprivation of liberty that may be done in public or private. ${ }^{2}$ Study suggests that violence against women prevails all over the world, through the form may vary from one society and culture to another. ${ }^{3}$ Maximum cases of gender based violence remains under reported due to social stigma, people feel shame to report cases of violence.

Gender-based violence is a global pandemic which affects 1 in 3 women. ${ }^{4}$ An estimated $30 \%$ of women between the age of 15-49 years suffered from gender based violence. Studies from India suggest a relatively high prevalence of gender-based violence and estimates vary widely, from $18 \%$ to $70 \%$. $^{5}$ There are different reasons for gender based violence, violence for having girl child is one of them. Many of women in own country still now feel the social and familial pressure for giving birth of boy baby. They often get threatening of abandonment of marriage, even get threatening of murder. Women are forced to have many pregnancies until a boy is born that also lead to poor maternal health.

Women's empowerment is the process in which women elaborate and recreate what they can be, they can do, and accomplish in a circumstance that they previously were denied. Empowerment the word itself says it creates power in oneself, society, and in their communities. Making the women empowered will help and give them a stronger voice in household decision-making and self-confidence that earns them respect in their households and in the wider community.

The objective of this study was to assess prevalence of gender based violence for having girl child, to find out women's own reaction, to assess level of women empowerment among subjects, to determine association between gender based violence and empowerment among women and to assess association between women's reaction and different demographic variables i.e. educational level, socio-economical level.

\section{Materials and Methods}

In the present study quantitative research approach and descriptive survey research design is used. The study was conducted in Post-Partum Unit of one Government Medical College and Hospital in West Bengal from October to November in the year 2020. The sample size is determined by using Cochran's formula and estimated sample size was 162. Non-probability purposive sampling technique was adopted to choose sample and 162 postnatal mothers were selected to conduct the study. Ethical clearance was obtained from Institutional Ethical Committee, $\mathrm{MCH}$, Kolkata. Formal permission was taken from Department of Health and Family Welfare, Government of West Bengal for final study. Pilot study was conducted Informed consent was taken before data collection from each sample Final data were collected over 6 weeks by using a validated and reliable semi-structured interview schedule $(r=0.98)$ and structured interview schedule $(r=0.83)$. Semi-structured interview schedule was administered to collect the sociodemographic information. Structured interview schedule was administered to assess the prevalence of gender based violence for having girl child, women's reaction and level of women empowerment.

\section{Inclusion Criteria}

The women who:

- $\quad$ Are willing to participate in the study.

- Have only girl children.

- Understand Bengali/English.

\section{Exclusion Criteria}

Women who are:

- Mentally Challenged.

- Single mother.

\section{Statistical Analyses}

The gathered data was entered in SPSS-23 software and to describe the data, frequency tables, statistical indicators and diagrams were used. To analyse the relationships between variables, related tests including the chi-square test, fisher's exact test were used.

\section{Result}

All (162) study participants were interviewed. Among them $126(77.77 \%)$ were between the age group of $21-30$ years. One hundred and thirty one $(80.86 \%)$ of women were from joint family. Women's education level up to primary level was in $43(26.54 \%)$ of women and were housewife in 150 (92.59\%) cases. Among them 146 (90.12\%) were from urban area. One hundred and twenty three $(75.92 \%)$ of women had only one child.

Figure 1, shows that $125(77.16 \%)$ of women did not face any violence where as it is unfortunate to mention that 37 (22.83\%) of women faced gender based violence for having girl child. The bar diagram shows that the commonest type of gender based violence is emotional violence (59\%), sexual violence is $57 \%$, economical violence is five percent and physical violence is also five percent.

The pie diagram in Figure 2, depicts that 148 (91.35\%) of 
women had no rejection of girl child, 14 (8.64\%) of had indifferent reaction for having girl child. No women had rejection of girl child.

The bar diagram in Figure 3, depicts that 104 (64.19\%) of women are well empowered, $58(35.80 \%)$ of women are moderately empowered and none are poorly empowered.

In the present study 136 (83.95\%) of women are well empowered in gender concern, in maternal health 130 $(80.24 \%)$ of women are well empowered, in case of personal \& FP matters 92 (56.79\%) of women are moderately empowered. One hundred and ten $(67.90 \%)$ of women are moderately empowered in economic indicator, in educational indicator 94 (58.02\%) of women are moderately empowered, in psychological indicator 131 (80.8\%) of women are well empowered, in social indicator 84 (51.85\%) of women are well empowered, 87 (53.70\%) of women are moderately empowered in political indicator.

Table I.Association between prevalence of gender based violence for having girl child and women empowerment

\begin{tabular}{|c|c|c|c|c|}
\hline & & & & $(n=162$ \\
\hline \multirow[t]{2}{*}{ Variables } & \multicolumn{2}{|c|}{$\begin{array}{c}\text { Prevalence of } \\
\text { gender based } \\
\text { violence }\end{array}$} & \multirow{2}{*}{$\begin{array}{c}\text { Total No. } \\
\text { (\%) }\end{array}$} & \multirow[t]{2}{*}{$x^{2}$} \\
\hline & $\begin{array}{l}\text { Present } \\
\text { No. (\%) }\end{array}$ & $\begin{array}{l}\text { Absent } \\
\text { No. (\%) }\end{array}$ & & \\
\hline $\begin{array}{c}\text { Well } \\
\text { empowered }\end{array}$ & 6 & 98 & 104 (64) & \multirow{2}{*}{$48.03 *$} \\
\hline $\begin{array}{l}\text { Moderately } \\
\text { empowered }\end{array}$ & 31 & 27 & $58(36)$ & \\
\hline Total & $37(23)$ & $125(77)$ & $162(100)$ & \\
\hline
\end{tabular}

Table 2.Association between women's reaction for having girl child and selected demographic variables

$(n=162)$

\begin{tabular}{|c|c|c|c|c|}
\hline \multirow[b]{2}{*}{ Variables } & \multicolumn{2}{|c|}{ Women's reaction } & \multirow[b]{2}{*}{$\begin{array}{l}\text { Total } \\
\text { No. } \\
(\%)\end{array}$} & \multirow[b]{2}{*}{$x^{2}$} \\
\hline & $\begin{array}{c}\text { No } \\
\text { rejection } \\
\text { No. (\%) }\end{array}$ & $\begin{array}{c}\text { Indifferent } \\
\text { No. (\%) }\end{array}$ & & \\
\hline \multicolumn{5}{|c|}{ Women's education } \\
\hline $\begin{array}{c}\text { Below } \\
\text { Madhyamik }\end{array}$ & 44 & 11 & $55(34)$ & \multirow{3}{*}{$11.51^{*}$} \\
\hline $\begin{array}{c}\text { Above } \\
\text { Madhyamik }\end{array}$ & 104 & 03 & $\begin{array}{l}107 \\
(66)\end{array}$ & \\
\hline Total & $148(91)$ & $14(9)$ & $\begin{array}{c}162 \\
(100)\end{array}$ & \\
\hline
\end{tabular}

Area of residence

\begin{tabular}{|l|l|l|l|l|}
\hline Urban & 136 & 10 & $\begin{array}{c}146 \\
(90)\end{array}$ & $3.93^{*}$ \\
\hline
\end{tabular}

\begin{tabular}{|c|c|c|c|c|}
\hline Rural & 12 & 04 & $16(10)$ & \\
\hline Total & $148(91)$ & $14(9)$ & $\begin{array}{c}162 \\
(100)\end{array}$ & \\
\hline
\end{tabular}

With Yates correction, $\chi 2$ value at $\mathrm{df}(1)=3.84, p<0.05$, *significant.

Table 1 , shows that chi square test is conducted between prevalence of gender based violence and women empowerment. The result reveals that obtained chi square value is 48.03 at degree of freedom (1), $p<0.05$. Therefore the inference can be drawn that there is significant association between prevalence of gender based violence for having girl child and women empowerment.

Table 2, reveals that there is association between women's education and women's reaction for having girl child, as the obtained chi square value with yates correction is 11.51 at $\mathrm{df}(1)=3.84, \mathrm{p}<0.05$. The result also reveals that there is association between area of residence and women's reaction for having girl child, as the obtained chi square value with yates correction is 3.93 at $\mathrm{df}(1)=3.84, \mathrm{p}<0.05$.

Table 3.Association between women's reaction for having girl child and selected demographic variables

$(n=162)$

\begin{tabular}{|c|c|c|c|c|}
\hline \multirow[b]{2}{*}{ Variables } & \multicolumn{2}{|c|}{ Women's reaction } & \multirow[b]{2}{*}{$\begin{array}{l}\text { Total } \\
\text { No. } \\
(\%)\end{array}$} & \multirow[b]{2}{*}{$\begin{array}{l}p \text {-value } \\
\text { of fisher } \\
\text { exact test }\end{array}$} \\
\hline & $\begin{array}{c}\text { No } \\
\text { rejection } \\
\text { No. (\%) }\end{array}$ & $\begin{array}{c}\text { Indiff- } \\
\text { erent } \\
\text { No. (\%) }\end{array}$ & & \\
\hline \multicolumn{5}{|c|}{ Number of child (ren) } \\
\hline One & 123 & 0 & $\begin{array}{l}123 \\
(76)\end{array}$ & \multirow{2}{*}{$0.00001^{*}$} \\
\hline $\begin{array}{l}\text { More than } \\
\text { one }\end{array}$ & 25 & 14 & $39(24)$ & \\
\hline Total & $148(91)$ & $14(9)$ & $\begin{array}{c}162 \\
(100)\end{array}$ & \\
\hline
\end{tabular}

\begin{tabular}{|c|c|c|c|c|}
\hline \multicolumn{2}{|l|}{ Family income } \\
\cline { 1 - 4 } $\begin{array}{c}\text { 10,000/- } \\
\text { and less }\end{array}$ & 90 & 14 & $\begin{array}{c}104 \\
(64)\end{array}$ & \multirow{2}{*}{$0.0023^{*}$} \\
\cline { 1 - 3 } $\begin{array}{c}\text { More than } \\
10,000 /-\end{array}$ & 58 & 0 & $58(36)$ & \\
\cline { 1 - 3 } Total & $148(91)$ & $14(9)$ & $\begin{array}{c}162 \\
(100)\end{array}$ & \\
\hline
\end{tabular}

With Fisher's Exact Test, $\mathrm{p}<0.05$ at df (1), * significant.

Table 3, reveals that there is association between number of children and women's reaction for having girl child, as the obtained p-value through Fisher's exact test is 0.00001 at df (1) which is less than 0.05 . The result also reveals that there is association between family income and women's reaction for having girl child, as the obtained p-value through Fisher's exact test is 0.0023 at $\mathrm{df}(1)$ which is less than 0.05 . 


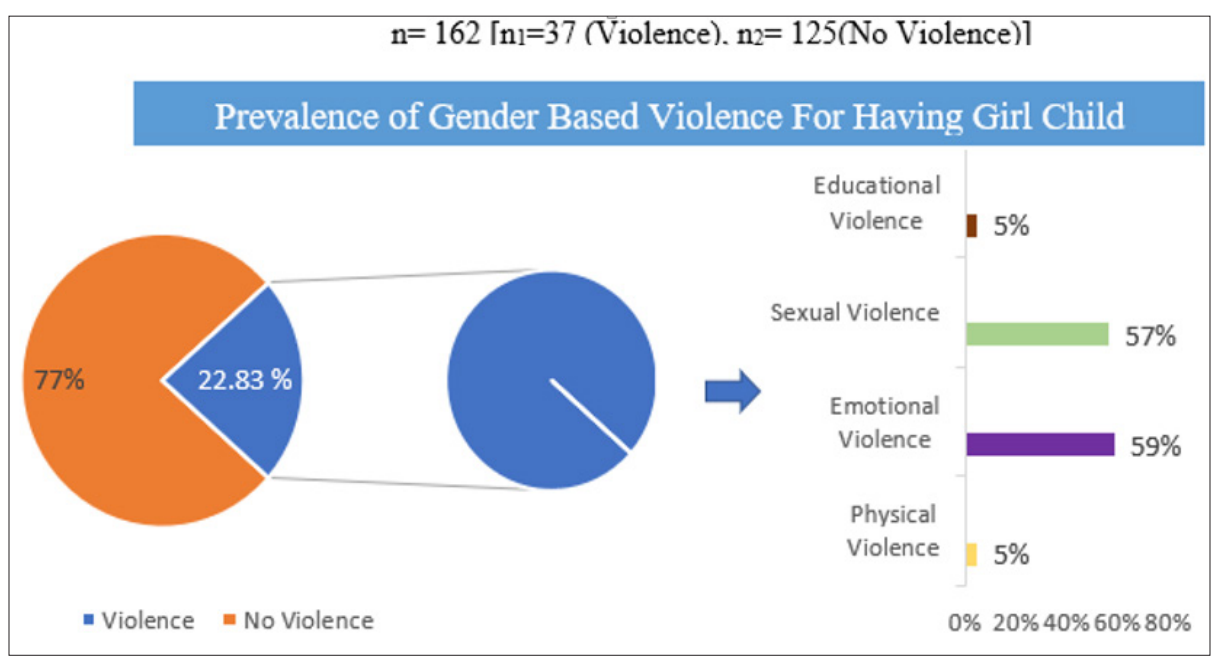

Figure I.Pie diagram and Bar diagram showing percentage distribution of women as per prevalence of gender based violence and their types

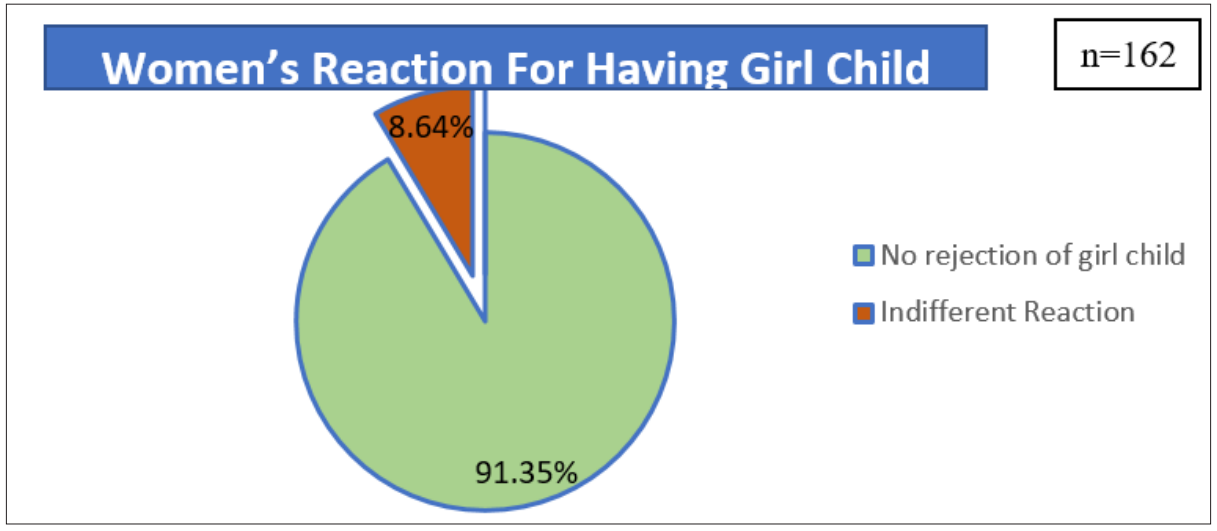

Figure 2.Pie diagram shows percentage distribution of women as per type of their reaction for having girl child

\section{Level of Women Empowerment}

$$
\mathrm{n}=162
$$
$64.19 \%$

$80.00 \%$
$60.00 \%$
$40.00 \%$
$20.00 \%$
$0.00 \%$

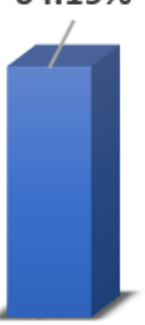

$35.80 \%$

- Well Empowered

Moderate Empowered

Figure 3.Bar diagram shows percentage distribution of women as per level of their empowerment

Table 4.Comparison of mean score of women empowerment between literate and illiterate group

$(n=162)$

\begin{tabular}{|c|c|c|c|c|}
\hline Education & Mean score of women empowerment & MD & SD & ' $t$ ' value \\
\hline Literate & 115.608 & 6.138 & 9.345 & $3.342 *$ \\
\hline Illiterate & 109.470 & & 7.700 & \\
\hline
\end{tabular}

*Significant at $d f=160, p<0.05$, table value 1.960. 
Table 4, depicts that mean score of literate group is 115.608 and illiterate group is 109.470 with the mean difference 6.138. Unpaired t-test was calculated to find out the true difference between two group's score. Here the t value is 3.342 at df 160 which is higher than the table value (1.960) at 0.05 level of significance. It means the mean difference is true difference between literate and illiterate group not by chance. Therefore there is significant difference of level of women empowerment between literate and illiterate group.

\section{Discussion}

The present study shows that $22.83 \%$ of women faced gender based violence for having girl child. This result is supported by, study of Corrinne PA, et al. which showed $15.5 \%$ violence present in urban area.6 Another study of Michele RD et al which showed prevalence of gender based violence was $10.2 \%$ to $36.6 \%$. $^{7}$ Similarly a study of Simister J which showed $13 \%$ of women faced violence. ${ }^{8}$ The study of Wang Tingting, Liu Yuvan, Li Zhanzhan et al showed prevalence of intimate partner violence was $7.7 \%{ }^{9}$

In the current study among gender based violence, physical violence faced by $5 \%$, emotional violence faced by $59 \%$, sexual violence faced by $57 \%$ and economical violence faced by $5 \%$ of women. A similar study by Benebo FO, Schumann B, Vaezghasemi showed $9.4 \%$ of physical violence, $3.7 \%$ of sexual violence, $15.7 \%$ emotional violence. ${ }^{10}$ Study of Nanda P, Gautam A, Verma R, Khanna A showed prevalence of physical violence was $21 \%$,emotional violence $18 \%$, economical violence $11 \%$, sexual violence $7 \% .{ }^{11}$

Majority of women (91.35\%) have no rejection of girl child and others (8.64\%) have indifferent reaction for having girl child. The present study is supported by a study by Kumar N, Kanchan T, Bhaskaran U et al which showed that majority of women $(60.6 \%, n=80)$ did not have any gender preference. ${ }^{12}$ Another study by Teichman Y, Rabinovitz D and Rabinovitz $Y$ which showed that women who were pregnant for first time didn't have any gender preference and who were pregnant for third time had preference for the gender which they didn't have. ${ }^{13}$

The present study shows there is significant (chi2 df (1) = $48.03^{*}, p<0.05$ ) association between gender based violence and women empowerment. The result consistent with a study conducted by Wekwete NN et al. which showed that women who did not participate in decision-making at household level were more likely to experience Gender based violence. ${ }^{14}$

\section{Conclusion}

The prevalence of gender based violence for having girl child is still now present in the society and the commonest form is emotional violence. Though the women are facing violence, they have no rejection of their girl child. The present study shows that gender based violence and women empowerment is significantly associated.

\section{Acknowledgement: Not any}

\section{Funding: No funding source}

Conflict of Interest: None

\section{References}

1. Violence against women. 2019. Available from: https:// en.m.wikipedia.org/wiki/Gender_violence.

2. Gender based violence. 2019. Available from: http:// www.humanitarianinfo.org/iasc/documents/subsidi/ tf gender/GBV/GBV\%20Guidelines\%20Introduction. pdf.

3. Kabir R, Ferdous N, Khan HT et al. Exploring the relationship of domestic violence on health seeking behaviour and empowerment of women in Pakistan. Epidemiology, Biostatistics and Public Health 2017; 14(1).

4. Gender based violence (Violence against women and girls). 2019. Available from: https://www.worldbank. org/en/topic/socialdevelopment/brief/violenceagainst-women-and-girls.

5. Stephenson R, Koenig MA, Acharya R et al. Domestic Violence, contraceptive use and unwanted pregnancy in rural India. Stud Fam Plann 2008; 39(3).

6. Corinne PA, Garcia L, Mc Aruthur D et al. Rural disparity in domestic violence prevalence and access to resources. J Womens Health (Larchmt) 2011; 20(11): 1743-9.

7. Michele RD et al. Understanding gender-based violence perpetration to create a safer future for women and girls. September 10,2013, 4(1); DOI: https://doi. org/10.1016/S2214-109X(13)70085-8 girls 2013. Available from https://www.thelancet.com/journals/ langlo/article/PIIS2214-109X(13)70085-8/fulltext.

8. Simister J. Gender-Based Violence is a growing problem in India. January 2018; 6(1). Available from https:// journals.ke-i.org/index.php/mra/article/view/1593

9. WangTingting, Liu Yuvan, Li Zhanzhan et al. Prevalence of intimate partner violence during pregnancy in China A systematic review and meta-analysis. October 2017

10. Benebo FO, Schumann B, Vaezghasemi M. Intimate partner violence against women in Nigeria: a multilevel study investigating the effect of women's status and community norms. BMC Women's Health 2013; 18(1): 136.

11. Nanda P, Gautam A, Verma R, Khanna A et al. Masculinity, Intimate Partner Violence and Son Preference in India. 2014: Available from https://asiapacific. unfpa.org/sites/default/files/pub-pdf/Study\%20 on\%20Masculinity\%2C\%20Intimate\%20Partner\%20 Violence\%20and\%20Son\%20Preference\%20in\%20 
India.pdf.

12. Kumar N, Kanchan T, Unnikrishnan B, Thapar R, Mithra P, Kulkarni V et al. Gender preferences among antenatal women: A cross-sectional study from coastal South India. 2015. African Health Sciences. 15. 561567. Available from: https://www.researchgate.net/ publication/277477335_Gender_preferences_among_ antenatal_women_A_cross-sectional_study_from_ coastal_South_India.

13. Teichman Y, Rabinovitz D and Rabinovitz Y. Gender preferences of pregnant women and emotional reaction to information regarding fetal gender and postpartum: An examination of freud's view about motivation for motherhood. March 1992.Doi: http://doi,org/10.1007/ BF00289706, Available from: https://link.springer.com/ article/10.1007/BF00289706\#citeas.

14. Wekwete NN, Sanhokwe H, Murenjekwa W et al. Spousal gender-based violence and women's empowerment in the 2010-2011 Zimbabwe demographic and health survey. Zimbabwe Working Papers, 2014. 